\title{
EVALUATION OF THE DEGREE OF SURFACE WATER POLLUTION OF THE ROS RIVER USING THE PHYTOINDICATION METHOD
}

\author{
Lavrinenko V. M., Kompanets E. V.
}

\section{INTRODUCTION}

On the riverbed of the river Ros, of the city Bila Tserkva, we found and identified 16 families (33 species) of macrophytes. We identified 4 groups among them: 1) submerged hydrophytes $(26 \%), 2$ ) hydrophytes with floating leaves $(42 \%), 3)$ free-floating hydrophytes $(8 \%)$, 4) helophytes $(8 \%)$. Dominants of phytocenotic aquatic groups are species - Carex acuata; Carex acutiformis, subdominants - Potamogeton berchololdii; Potamogeton obtusifolius. Water cenosis formed by the species: Potamogeton, Lemna minor and Cladophora form thickets, which are characterized by a total projective coverage of 60 to $100 \%$. The index of the Mayer $\mathrm{IM}^{1}$ and the macrophytic index $\mathrm{MI}^{2}$ indicate the third class of water quality, which meets the criteria of moderately polluted and "polluted". Indicators of pollution are species - Potamogeton berchololdii and Lemna minor.

Today, most reservoirs are under the influence of urbanization and largescale industrialization. The development of ecology problems has led to new ideas for monitoring and assessing the state of aquatic ecosystems. One of the promising areas of research to assess the state of aquatic ecosystems is the use of phytoindication.

The biological method of assessing the state of the reservoir allows us to solve the problems that cannot be solved by hydrophysical and hydrochemical methods. Assessing the degree of pollution of the water body by the composition of living organisms, you can quickly establish its sanitary condition, determine the pollution degree of, to quantify the processes of natural self-purification of reservoirs.

These days, macrophytes have been used as bioindicators to monitor the state of surface water. Macrophytes are a powerful autotrophic block of aquatic ecosystems. They are sensitive to changes in the state of their environment. Any change in the hydrochemical regime of the water body,

\footnotetext{
${ }^{1}$ Куцонь Ю.А. Сучасний стан рибного населення басейну річки Рось. 2010. URL: http://librar.org.ua/sections_load.php?s=biological_sciences\&id=1582\&start=1 .

2 Гамалій І.П. Еколого-географічні аспекти водних ландшафтно-інженерних систем басейну р. Рось. Київ. 2008. URL: https://docviewer.yandex.ua.
} 
associated with anthropogenic impact, can lead to changes in the composition of the biota. Therefore, the change in species diversity, nature, and degree of vegetation development is an indicator of water quality. Knowing the species composition and dynamics of the number of indicator species, we can assess the quality of the water body and its ecological condition. $^{3}$

Novadays, the situation with water pollution is typical for the whole territory of Ukraine, but our object was the river Ros of Bila Tserkva city. The problem of pollution of the Ros river is relevant because every year the situation becomes more complicated and the water becomes unfit for drinking and bathing. Bioindication methods of study of macrophytes were described in the works of many rescarches, amond them are: Babiy P.O. (2016), Gamaliy I.P. (2008), Khilchevsky V.K., Kurylo S.M., Savitsky V.M., Silevych S.O. (2007), Kutsokon (2007, 2010), Karpova G. (2010), Shevchuk I.O., Zatsarina O.D., Sukacha L.V., Jacyka A.V., Hopchak I.V. and Basyuk T.O. (2013).

In their works, they note that the use of certain species of macrophytes as indicators of the ecological condition of water bodies seems extremely attractive. They are visible and easy-to-observe objects, as the vegetation cover is flexible and sensitive to changes in the environment. It reflects a set of characteristics of the reservoir: hydrological state, trophic status, stage of development. Even a small survey of vegetation in the water allows you to make a rapid assessment of its ecological condition.

However, most macrophytes adapt to changes in the environment easily. This allows them to live in water body with a wide range of physical and chemical parameters. Indication by macrophytes has certain limitations. It is possible only when the reservoir has a certain set of external conditions favorable for the development of aquatic plants, namely air velocity, the presence of shallow water protected from wind and waves, water transparency, etc. ${ }^{4}$

The river Ros belongs to the group of rivers of mixed type, which indicates a rich diversity. However due to the strong anthropogenic load, hydrobiological composition of water is changing that dangerous to public health.

The aim of the research is to assess the degree of pollution of surface water of the Ros river using the method of phytoindication.

Objectives of the study:

- to analyze the species diversity of the main groups of aquatic macrophytes of the Ros river coastal area;

\footnotetext{
${ }^{3}$ Білявський Г.О. Основи екології : підручник. Київ : Либідь, 2006. 324 с.

4 Определитель высших растений Украины / Д.Н. Доброчаева и др. Киев : Наукова думка, 1987. 548 с.
} 
- to determine the degree of pollution of the river by the Mayer index;

- to establish a macrophytic index of the studied sections of the Ros river;

- to develop recommendations for improving the condition of water bodies of the Ros river.

The object of the study was macrophytes of the Ros river reservoir in the territory of the city of Bila Tserkva.

Research methods. During the research were used: theoretical methods analysis of the scientific literature, study of the method of bioindication of the aquatic environment using Mayer's method, and the macrophytic index. Comparative method was insed to compare the results of observation of the diversity of aquatic macrophytes on the indicators of the modified Mayer index and the macrophytic index. Analytical method - analysis of the state of river pollution, analysis of the species composition of macrophytes. The observation method - is the observation of higher aquatic plants diversity.

An element of scientific novelty of the obtained results is the assessment of certain areas of the coastal zone of the Ros river, which are subject to strong anthropogenic impact on the modified index and Mayer's index, that allows to use this research material during the development of the program for optimal socio-economic development of Bila Tserkva.

The results were used to develop the program for optimal development of Bila Tserkva city, and included to the "Regional Environmental Program for 2016-2020", for improving the existing recreational area near the Ros river, as well as to improve the quality and quantity of water in the river.

\section{Ecological condition of the river Ros}

Aquatic macrophytes are a group of plants that can grow in the aquatic environment or places of excess moisture. Macrophytes are part of the ecosystems of most water bodies. They affect hydrochemical and hydrobiological processes. First of all, macrophytes, in the process of photosynthesis, release oxygen enriching water with it, and are food and shelter for some inhabitants of water body. Aquatic plants are of great importance for puriffing water bodies from pollution. Their thickets act as a mechanical filter, clarifying the water, protecting the shores of water body from erosion. Plants in their tissues accumulate significant concentrations of various pollutants - heavy metal ions, pesticides, radionuclides. ${ }^{5}$

Among all the variety of aquatic plants, some species do not withstand the slightest pollution and can live only in clean water. Some, on the contrary, can not only exist but also withstand high concentrations of

${ }^{5}$ Білявський Г.О., Фурдій Р.С., Костіков І.Ю. Основи екології : підручник ; 3-є вид. Київ : Либідь, 2006. 324 с. 
pollutants. They are used as natural biofilters based on these features of macrophytes.

Depending on the method of adaptation to the aquatic environment, macrophytes are divided into two groups - gelophytes and hydrophytes.

Gelophytes are plants whose rhizome and lower part of the stem are in water and the upper part is in the air. Dense thickets of these species form a belt along the shore of the reservoir. They perform the following environmental functions: protect shores from destruction and clean polluted surface runoff. However, plants of this group, after the death and decomposition of phytomass become a source of secondary pollution of the reservoir, forming productive thickets.

Hydrophytes are plants that float freely on the surface or are completely immersed in water. They have no roots, move easily downstream. The group of hydrophytes depends on the ecological condition of the water body. Hydrophytes are the most sensitive indicators among other aquatic plants. ${ }^{6}$

Due to the fact that the living conditions of macrophytes can be extremely variable (shallow water, flooding), most plant species are characterized by polymorphism. As a result, some species can move from air-water form to submerged, in the first case they form sticky stems and leaves and the second case-soft ones.

The degree of development of plants of different ecological groups in the water body can be used as an indicator of its ecological state. Excessive development of the belt of air-water plants indicates the shallowing of the water body and its waterlogging. It is believed that the development of helophytes more than $30 \%$ of its area is critical for the water body. Significant growth of plants with floating leaves is an indicator of the lack of flow of the water body, stagnation, increased trophic levels, and deterioration of water quality. The dominance of submerged macrophytes in the water body indicates its good ecological condition ${ }^{7}$.

Usually, different parts of a reservoir or river are under the influence of various environmental factors. The more temperate the conditions of the aquatic ecosystem are, the greater biodiversity is.

The Ros river is a medium-sized river with water loss in the non-flood period up to $5 \mathrm{~m}^{3} / \mathrm{s}$, flow rate up to $0,2 \mathrm{~m} / \mathrm{s}$. The Ros river finds it source in Vinnytsia oblast, flows through Kyiv oblast, and flows into the Dnieper in Cherkasy oblast. The source of the river is located near the Ordyntsi village,

${ }^{6}$ Географічна енциклопедія України : у 3-х т. / редкол.: О.М. Маринич (відп. ред.) та ін. Київ : Українська радянська енциклопедія» ім. М.П. Бажана, 1989. Т. 1: А-Ж. 416 c.

7 Гамалій І.П. Еколого-географічні аспекти водних ландшафтно-інженерних систем басейну р. Рось. Київ. 2008. URL: https://docviewer.yandex.ua. 
Pohrebyshche region, Vinnytsia oblast an altitude of $270 \mathrm{~m}$ above sea level. The river flows northeast from Bila Tserkva - to the southeast and east below Korsun-Shevchenkivskyi, turns north in the estuary - again to the northeast and east and flows into the Dnieper to the north of Khreschatyk village (Cherkasy oblast) at an altitude of $70 \mathrm{~m}$ above sea level.

The climate of the Ros river basin is moderately warm and humid. The average annual temperature is $6,6-7,20^{\circ} \mathrm{C}$, January to $-6,40^{\circ} \mathrm{C}$, July to $+19,80^{\circ} \mathrm{C}$. Under the conditions of feeding the river is of mixed type. Rock outcrops and blurred soils are found along the entire length of the river. The river is characterized by floods, low summer flows. Most of the annual runoff $-50-60 \%$ takes place during spring floods, $20-25 \%$ - in summer and autumn, $15 \%$ - in winter. Such data indicate a high saturation of biodiversity in the ecosystem of the Ros river. Indicators in such an ecosystem can be different groups of macrophytes.

Based on the works of Gamaliy I.P. (2007), Shvayun I.V. (2006), Romanenko V.D. (2001) on the water of the Ros there is an increase in nitrogen content to $3.57 \mathrm{mg} / \mathrm{l}$. The content of suspended solids in the Ros river in winter is up to $20 \mathrm{mg} / 1$. In the tributaries of the river $10-15 \mathrm{mg} / 1$. The growth of water mineralization occurs during the winter-low tide. The process itself is carried out due to sulfate ions and bicarbonates. There is an increased content of ammonium nitrogen, nitrates, phosphates. Within the city of Bila Tserkva, these figures exceed 1.5-2 times. There is an impact of soil, and surface runoff from urban areas (petroleum products, heavy metals). ${ }^{8}$

In most small rivers of the Ros basin, pollution by petroleum products and nitrogen compounds is observed. In some places, the maximum concentration limit for HSC and some heavy metals (copper, zinc, nickel) was exceeded. The respective regime is not observed in the territories of water protection zones and coastal strips. The requirements for growing crops are not met. In this regard, the river and its tributaries are washed away from the fields of organic matter, mineral fertilizers, pesticides, fertile soil. Agricultural use of land averages $71 \%$, and forest cover is only $11 \% .^{9}{ }^{10}$

Large volumes of wastewater discharges cause a decrease in the water quality of small rivers in the Ros river basin. Shallowing is observed, the water level decreases annually. This leads to siltation and waterlogging of the river. The decrease in the water content of the river is due to the extraction of water for the needs of the farm. It is concluded that the main

${ }^{8}$ Романенко В.Д. Основи гідроекології : підручник. Київ : Обереги, 2001. 728 с.

9 Аркадіївна А. Рослинність долини р. Рось: синтаксономія, антропогенна динаміка, охорона. 2005. URL: https://docviewer.yandex.ua.

${ }^{10}$ Гамалій І.П. Екологічний стан водних антропогенних ландшафтів басейну р. Рось. Наукові записки Вінницького державного педагогічного університету імені Михайла Кочюбинського. Серія «Географія». 2007. Вип. 13. С. 134-139. 
reason for the decline in river water quality is the deterioration of their selfcleaning capacity. Physicochemical and biological mechanisms of selfpurification were violated. The first-priority measures to improve the ecological condition of the surface water of the Ros river basin are the clearing of the old channel. It will stop the processes of waterlogging, the creation of water protection zones, and coastal water protection zones. The obtained results can be used to keep the slopes of the river valleys intact, to minimize the use of floodplains in agricultural production, to reduce plowing along the shoreline. ${ }^{11}$

Moreover, the Ros River valley is a promising site for inclusion in the Emerald Network. There are some species of flora and fauna, as well as habitats that must be protected under national law and the Berne Convention. Within the valley of the Ros river, plant species listed in the Red Book of Ukraine are widespread: Allium ursinum L., Pulsatilla pratensis (L.) Mill., Fritillaria meleagris L., Daphne cneorum L., Platanthera bifolia (L.) L.C.Rich., Epipactis helleborine (L.) Crantz, Scopolia carniolica Jacq., and others. $^{12,13}$

Also animals - Granaria frumentum D., Lucanus cervus L., Bombina bombina L., Haliaeetus albicilla L., Haematopus ostralegus L., Mustela erminea L., Myotis nattereri Kuhl. etc. ${ }^{14}$

In addition, in the valley of the Ros River, there are habitats of rare syntaxon listed in the Green Book of Ukraine, in particular, rare relict groups (Salvinieta natant, Trapeta natantis formations), rare and endangered relict groups on the southern boundary of the range), typical relict groups (formations of Nymphaeeta albae, Nuphareta luteae), rare groups on the northern boundary of the range (Stipeta capillatae, Stipeta borysthenicae), groups with a rare type of association of the dominant of the main tier of the truss (cneori), Fraxineto (excelsioris) - Quercetum (roboris) alliosum (ursini)). ${ }^{15}$

In particular, according to Arkadyeva A. (2005), the natural vegetation of the Ros River is represented by groups belonging to 14 classes, 26 orders, 45 unions, 104 associations, 4 sub-associations, and 59 variations.

11 Особливості гідрохімічного режиму р. Рось / В.К. Хільчевський та ін. Гідрологія, гідрохімія і гідроекологія. 2007. Т. 12. С. 132.

12 Куземко А.А. Охорона флори і рослинності долини р. Рось. Украӥнський ботанічний журнал. 2002. Т. 59. № 5. С. 569-577.

13 Червона книга України. Рослинний світ / за ред. Я.П. Дідуха. Київ : Глобалконсалтинг, 2009. 900 с.

${ }^{14}$ Мережа NATURA 2000 як інноваційна система охорони рідкісних видів та оселищ в Україні / Д.В. Ширяєва та ін. Матеріали науково-практичного семінару, м. Київ, 15 лютого 2017 р. / Серія «Conservation Biology in Ukraine». Вип. 1. С. 234-238.

15 Куземко А.А. Охорона флори і рослинності долини р. Рось. Украӥнський ботанічний журнал. 2002. Т. 59. № 5. С. 569-577. 
Synanthropic flora consists of 8 classes, 11 orders, 13 unions, 28 associations, and 11 options. ${ }^{16}$

Sixteen families are the flora of the river Ros, among them: Ranunculaceae, Brassicaceae, Cuperaceae, Numphaeaceae, Poaceae, Primulaceae, Lemnaceae, Polugonaceae, Potamogetonaceae, Butomaceae Nelumbonaceae, Araliaceae, Thelupteridaceae, Trapaceae, Tupha, Scrophulariaceae. Among them, six families have the largest number of indicator species: Brassicaceae - three types: Cardamine parviflora L.; Nasturtium officinale R.Br., Rorippa austriaca (Crantz) Bess. Family Cuperaceae, seven species - Carex acuata L. Carex acutiformis Ehrh.,Carex elata Meinsh., Carex pseudocyperus L., Eleocharis aciculare (L.) Room. Et Schult., Scirpus lacustris L. Family Numphaeaceae represented by two species: Ceratophyllum demarsum L., Ceratophyllum sumbersum L. Family - Butomaceae represented by one species Elodea Canadensis Michx. Family Poaceae - three speciees: Gluceria maxima (C. Hartm) Holmb., Gluceria plicata Fries., Phragmites australis (Cav.) Trin. ex. Steud. To the family Tupha belong to the Tupha angunstifolia L., and Tupha latifolia L. Ten families have only one species: Ranunculaceae (Batrachlum carinatum Schur.), Primulaceae (Hutonia palustris L.), Polugonaceae (Pologonum amphibium L.), Nelumbonaceae (Ranunculus poluphyllus Waldst. et Kit.), Araliaceae (Sium latifolium L.) Thelupteridaceae (Thelupteris palustris Schott.), Trapaceae (Trapa natans L.), Scrophulariaceae (Veronica beccabunga L.).

The phytocenotic diversity of the Ros river is characterized by a high degree of ecotopes in the direction from the watershed to the channel and from the sources to the mouth. The coastline is represented by subdominant species: Phragmites australis, Gluceria maxima, Tupha angunstifolia and Tupha latifolia. ${ }^{17}$

The Ros river is also rich in phytoplankton. Indicators of phytoplankton are algae: green algae (Chlorophyta) - 25 species, diatoms algae (Bacillariophyta) - 10 species, blue-green algae (Cyanophyta) -8 species. ${ }^{18}$

Dominant phytoplankton complexes of green algae indicate a fairly high degree of eutrophication of the Ros river and the presence of organic pollutants. ${ }^{19}$

16 Аркадіївна А. Рослинність долини р. Рось: синтаксономія, антропогенна динаміка, охорона. 2005. URL: https://docviewer.yandex.ua.

${ }^{17}$ Гавриленко О.П. Екогеографія України : навчальний посібник. Київ : Знання, 2008. $128 \mathrm{c}$

18 Зеркалов Д.В. Екологічна безпека та охорона довкілля : монографія. Київ : Основа, 2011. URL: https://docviewer.yandex.ua/?url=http\%3A\%2F\%2Fzerkalov.org.

19 Гідробіологічний режим і стан річкової флори та фауни. URL: http://www.novaecologia.org/voecos-2369. 
Zooplankton is one of the main elements of groups of aquatic animals that play an important role in shaping the quality of water and fish feed. The zooplankton of the Ros River is characterized by relatively poor species composition and qualitative development. The number of zooplankton species is smaller in the regulated sections of the river than in the unregulated ones, but the level of quantitative development is much higher. The species composition and amount of zooplankton increases from the source (minimum value) to the mouth. Assessing the overall sanitary biological condition of the water of the river Ros and the main tributaries of zooplankton the saprobity index is $1,6-1,9$. This corresponds to the beta mesosamp state, the water body is moderately polluted. The number of mesoexperimental organisms is an indicator of the level of water pollution, its vital activity it contributes to its purification. In the seasonal aspect, it is necessary to note the growth of the saprobity index in autumn and especially in winter, which indicates a higher level of pollution. ${ }^{20}$

The faunistic composition of the water in the mouth of the river quantitavely is characterized by following indicators: bream $-4.5 \%$; roach $49 \%$; silver bream $-16 \%$; perch $-12 \%$; pike perch $-1.5 \%$; pike $-9.4 \%$; blue bream $-5 \%$; ide $-1.6 \%$; others $-8 \%$. ${ }^{21}$

Anthropogenic pressures have significantly changed the ecological living conditions of fish in the lower reaches of the Ros river, which has significantly affected the structure of fish groups, both qualitatively and quantitatively. In the estuary of Ros, some species of goby, the three-spined stickleback, the Black Sea pelagic pipefis, and the Black Sea sprat which come here en masse for feeding are widespread. There are even more fish population on the upper reaches of the river. There is a predominance of fish species of the lake - river complex (perch, roach, pike, rarely - tench, crucian, bream, gunther, bitter gourd) and to a lesser extent rheophilic species - ide, sandpiper, fir, spike. In the upper part of the river Ros were found 16 species of fish. ${ }^{22}$

20 Звіт 3 оцінки впливу на довкілля виконання робіт щодо відновлення гідрологічного режиму Гідрологічного заказника «Зелені криниці», що розташований за межами села Ординці на території Левківської сільської ради Погребищенського району Вінницької області. Вінниця 2019. 59 с. URL: http://eia.menr.gov.ua/uploads/documents/ 2062/reports/dbb6daa358ad77edf99ae2a37f78f05d.pdf.

${ }^{21}$ Шваюн І.В. До питання видового складу іхтіофауни р. Рось . Тези доповідей $V$ державної науково-практичної конферениії «Аграрна наука - виробництву», м. Біла Церква, 23-25 листопада 2006 р. Біла Церква, 2006. Ч. 1. С. 118.

22 Звіт 3 оцінки впливу на довкілля виконання робіт щодо відновлення гідрологічного режиму Гідрологічного заказника «Зелені криниці», що розташований за межами села Ординці на території Левківської сільської ради Погребищенського району Вінницької області. Вінниця 2019. 59 с. URL: http://eia.menr.gov.ua/uploads/documents/2062/reports/dbb6daa358ad77edf99ae2a 37f78f05d.pdf. 
Ichthyofauna of the river was replenished with plant species even earlier. Due to natural food base amur acclimatizer are provided with food almost completely. In recent yars near the middle course of the river, almost 22 fish species were registered. ${ }^{23}$

Thus, flora and fauna of the river are quite diverse but due to human influence the hydrobiological regime of the river is constantly changing, so the priority is to monitor the quality of river water using indicators.

\section{Phytoindication of surface waters of the Ros River}

\section{and recommendations for improving the condition of the reservoir}

To determine the assessment of the ecological status of the water of the Ros River, research was conducted in several stages. Initially, the species diversity of macrophytes was assessed. Then they identified the species and established what role they played in the group, acting as dominants or subdominants. Particular attention was paid to the dominant species. Because they reflect the overall picture of the water body state. For division of macrophytes we used the classification of two ecological groups of geloand hydrophytes.

Moreover, in order to detect changes that are taking place in the water body, we relied on the spatial distribution of the phytocenosis. Macrophyte species were studied in four zones. The first zone is located on the waterfront facility and in the coastal fringes of the river. It is formed by helophytes with a small height.

In the first zone, we found and identified such species as Carex acuata $\mathrm{L}$. and Carex elata Meinsh.

The second zone was formed by tall helophytes. They occupy areas with a depth of not more than $50 \mathrm{~cm}$. These included species: Phragmites australis (Cav.) Trin. ex. Steud, Tupha angunstifolia L. and Tupha latifolia L.

The third belt was formed by hydrophytes located at depths of 0,5-1,5 m. It consisted of such species of macrophytes as Trapa natans L., Batrachlum carinatum Schur.

The fourth zone is formed by submerged macrophytes. It is typical for depths of 0,5-2,5 m. Representatives of this belt are Potamogeton obtusifolius Mert. et Koch., Potamogeton pectinatus L., Potamogeton trichoides Schlecht. et Cham., Potamogeton compressus L., Elodea Canadensis Michx.

We found that in each zone of the coastal part of the water body there is no or low development of the belt of short and tall macrophytes. Plants are dormant, especially in areas of bathing and recreation. Overgrowth of the

23 Зеленая книга Украинской ССР / под общ. ред. Ю.Р. Шелег-Сосонко. Киев : Наук. думка, 1987. 
shoreline occurs in some areas along the river Ros in Bila Tserkva. These areas are downstream, that cause increaling of the amount of plant thickets. Usually, these plants are not typical for the coastal zone of the water body. Among them are Lemna minor L. та Lemna trisulca L., Ceratophyllum demarsum L., Rorippa austriaca (Crantz) Bess., Gluceria maxima (C. Hartm) Holmb.

The high level of tolerance of certain species macrophytes makes it impossible to use them as indicators in bioindication studies. The ability to ecological plasticity (EP) is found in many groups of aquatic plants and allows them to exist even in a highly polluted ecosystem. Indicators of waterlogging in some floodplains were: Phragmites australis (Cav.) Trin. ex. Steud., Carex acuata L., Carex acutiformis Ehrh., Carex elata Meinsh. Lemna minor L., Lemna trisulca L.

We identified thirty-three dominant species, $30 \%$ of which belonged to the heleophyte group (Table 1).

According to the table, thirty-three species belong to 16 families: Ranunculaceae, Brassicaceae, Cuperaceae, Numphaeaceae, Butomaceae, Poaceae Primulaceae, Lemnaceae, Polugonaceae, Potamogetonaceae, Nelumbonaceae, Araliaceae, Thelupteridaceae, Trapaceae, Tupha, Scrophulariaceae.

We identified four subgroups, namely 1) submerged hydrophytes (26\%),

2) hydrophytes with floating leaves $(42 \%), 3)$ free-floating hydrophytes $(8 \%), 4)$ helophytes $(8 \%)$.

Species that were the dominant macrophytes (indicators) belong to the femilies: Cuperaceae - Carex acuata; Carex acutiformis; Carex elata; Carex pseudocyperus; Eleocharis aciculare; Scirpus lacustris and family Potamogetonaceae - Potamogeton berchololdii; Potamogeton obtusifolius; Potamogeton pectinatus; Potamogeton trichoides; Potamogeton compressus.

Submerged hydrophytes along the shores can occupy the entire shallow zone, the width of which reaches 20-50-70 m (along the coastline of Bila Tserkva). Slight in area, aquatic cenoses form - Potamogeton crispus and Myriophyllum spicatum. There are separate specimens of $P$. perfoliatus, $P$. trichoides, but they do not form cenoses. Thickets are characterized by total projective cover of up to $100 \%$ (plants usually fill the entire water column) and high phytomass.

It is noticed significant development of free-floating plants - Spirodela polyrhiza, Lemna minor (up to $80 \%$ of the projective cover). The vast majority of species belong to the limnophilous and eutrophic-swamp complexes. The spatial distribution of macrophytes is zonal the significant development of the zone of high-trophic helophytes indicates the process of shallow waterlogging due to the lack of rinsing. 
Table 1

Macrophytes-dominants and subdominants were found during the study of the shoreline of the river Ros

\begin{tabular}{|c|c|c|c|}
\hline №. & Species & IM & MI \\
\hline 1 & Batrachlum carinatum Schur. & $\mathrm{B}$ & 7 \\
\hline 2 & Cardamine parviflora $\mathrm{L}$. & B & - \\
\hline 3 & Nasturtium officinale R.Br. & - & - \\
\hline 4 & Rorippa austriaca (Crantz) Bess. & $\mathrm{B}$ & 5 \\
\hline 5 & Carex acuata $\mathrm{L}$ & B & - \\
\hline 6 & Carex acutiformis Ehrh. & $\mathrm{B}$ & - \\
\hline 7 & Carex elata Meinsh. & $\mathrm{B}$ & - \\
\hline 8 & Carex pseudocyperus $\mathrm{L}$. & $\mathrm{B}$ & - \\
\hline 9 & Eleocharis aciculare (L.) Room. Et Schult. & - & - \\
\hline 10 & Scirpus lacustris L. & - & - \\
\hline 11 & Ceratophyllum demarsum $\mathrm{L}$. & - & - \\
\hline 12 & Ceratophyllum sumbersum $L$. & - & - \\
\hline 13 & Elodea Canadensis Michx. & $\mathrm{B}$ & 5 \\
\hline 14 & Gluceria maxima (C. Hartm) Holmb. & B & - \\
\hline 15 & Gluceria plicata Fries. & B & - \\
\hline 16 & Phragmites australis (Cav.) Trin. ex. Steud. & $\mathrm{B}$ & - \\
\hline 17 & Hutonia palustris $\mathrm{L}$. & $\mathrm{C}$ & 7 \\
\hline 18 & Lemna minor L. & $\mathrm{C}$ & 8 \\
\hline 19 & Lemna trisulca $\mathrm{L}$. & $\mathrm{C}$ & 8 \\
\hline 20 & Spirodela polyrrhyza (L.) Schleid. & $\mathrm{C}$ & 7 \\
\hline 21 & Pologonum amphibium L. & - & - \\
\hline 22 & Potamogeton berchololdii Fries. & $\mathrm{B}$ & 8 \\
\hline 23 & Potamogeton obtusifolius Mert. et Koch. & $\mathrm{B}$ & 7 \\
\hline 24 & Potamogeton pectinatus L. & $\mathrm{C}$ & 8 \\
\hline 25 & Potamogeton trichoides Schlecht. et Cham. & $\mathrm{C}$ & 7 \\
\hline 26 & Potamogeton compressus $\mathrm{L}$. & $\mathrm{C}$ & 8 \\
\hline 27 & Ranunculus poluphyllus Waldst. et Kit. & - & - \\
\hline 28 & Sium latifolium $\mathrm{L}$. & - & - \\
\hline 29 & Thelupteris palustris Schott. & - & - \\
\hline 30 & Trapa natans $\mathrm{L}$. & B & 7 \\
\hline 31 & Tupha angunstifolia $\mathrm{L}$. & B & 5 \\
\hline 32 & Tupha latifolia $\mathrm{L}$. & B & - \\
\hline 33 & Veronica beccabunga $\mathrm{L}$. & - & - \\
\hline
\end{tabular}

During the survey of the riverbank in Bila Tserkva attention was paid to the degree of overgrowth of the water body ( $\%$ of the area occupied by macrophyte thickets, of the total area), and dominant groups (indicators) of macrophytes and their abundance to determine the modified Mayer's index, and macrophytic index. 
It was found that along the shoreline the degree of overgrowth of the water body is characterized as medium and high and ranges from $40 \%$ to $60 \%$. Dominants of the coastal - aquatic vegetation of the studied areas are Carex acuata, Phragmites australis, subdominant - Lemna minor.

There are a few indicators of water pollution among the detected macrophytes. We selected and systematized the identified aquatic plants into two groups (B,C), according to the modified Mayer's index. Groups B, $\mathrm{C}$ include the following species: (B) - Batrachlum carinatum, Cardamine parviflora, Rorippa austriaca, Carex acuata, Carex acutiformis, Carex elata, Carex pseudocyperus, Elodea Canadensis, Gluceria maxima, Gluceria plicata, Phragmites australis, (C) - Potamogeton pectinatus, Potamogeton trichoides, Potamogeton compressus, Hutonia palustris, Lemna minor, Lemna trisulca, Spirodela polyrrhyza.

After calculations according to Mayer's formula, we found that the coefficient is 15 and 18. The average index of MI is 16. This allows us to define this water body as $\beta$ - mesosaprobic, which has $3^{\text {rd }}$ class of water quality, moderately polluted. Our ratio is 16. It approaches the lower threshold. This is extremely dangerous because dirty $\alpha$-mesosaprobic or polysaprobnazone has a score below 15 points. Thus, according to the modified Mayer's index the water along the riverbank of the city of Bila Tserkva is moderately polluted. It corresponds to the $\beta$-mesosaprobic zone with the indicator "moderately polluted".

For more result of accurate research, we chose the Macrophyte Index. According to the macrophytic index (MI), indicator 8 had the following types: Lemna trisulca, Lemna minor, Potamogeton berchololdii, Potamogeton pectinatus, Potamogeton compressus. Indicator MI 7 had the following types: Trapa natans, Potamogeton trichoides, Potamogeton obtusifolius, Hutonia palustris, Spirodela polyrrhyza, Hutonia palustris, Batrachlum carinatum. Indicator MI 5 had the following types: Rorippa austriaca, Elodea Canadensis, Tupha angunstifolia. All indicators are present in the table 1. The average indicator of the Macrophytic Index (MI) in the studied areas is 6,6. It corresponds to the III class of water "polluted".

Among the general diversity of macrophytes, only a relatively small part has relatively clear indicator properties and can be used to determine water quality. As a result of long-term observations of the aquatic vegetation of different types of reservoirs of Ukraine, macrophyte species were combined into 7 indicator groups. This division is based on the similarity of reactions to pollution. Thus, the method of research by the Macrophyte Index confirmed the indicator of water - "polluted".

Today, in response to pollution of the Ros river, the Bila Tserkva region administration has appealed to the Ministry of Ecology and Natural 
Resources of Ukraine to pay attention to the ecological catastrophe of the river and to improve its ecological condition in the Bila Tserkva region of Kyiv oblast.

As a result, the project "Save Ros for Descendants" was developed the aim of which was

1. To foster the ecological world outlook and ecological culture of youth.

2. To promote the dissemination of environmental knowledge.

3 . To master the rules of environmental managment.

4. To involve young people in environmental activities on the basis of knowledge acquired at school.

5. To develop information and technological competencies of students.

6. To study the water in the river Ros.

7. Develop educational materials based on the results of research of the Ros river.

8. Carry out training and promotion of the idea of preserving the Ros river for descendants in schools and institutions of the region.

The proposed measures should be aimed at organizing public action and eliminating the factors of negative impact on the river. To date, in our opinion, there are 3 areas of river rehabilitation.

Firstly, the cessation and elimination of all phenomena that is leading to land erosion and soil erosion and, as a consequence, pollution of the Ros river.

Secondly, restriction of economic intervention in the river valley as maximum as possible.

Thirdly, to clear the riverbeds from man-made structures and to prevent of changes in the floodplain (after the environmental justification), in particular, the construction of canals, locks, ponds, created without prior design.

Therefore, we consider the following to be the main possible measures to improve the ecological condition of the Ros river:

- carrying out of ecological-educational actions with inhabitants of nearby settlements;

- control of economic activity in the river basin by local executive bodies by current legislation, public participation in it;

- cessation of plowing of coastal zones, their local marking;

- rationing of cattle and poultry grazing in the river valley;

- gradual withdrawal from the river valley of farm and residential buildings that have a detrimental effect on the river Ros;

- wastewater treatment from specific enterprises and utilities;

- creation of forest or shrub plantations in the river valley;

- reconstruction (or, maybe, liquidation) of poorly constructed hydraulic and other artificial structures that regulate the flow of the Ros river; 
- restoration of the natural flow of the river;

- mowing excessive amounts of aquatic vegetation;

- protection of spawning grounds for fish, habitats of wetland animals;

- protection of rare plant species in the river valley;

- creation of an organization for the protection of river research with the representatives from atate and public institutions.

These measures are a priority and do not require significant funds. They should encourage the public to solve the river's problems. For the general stabilization of the situation, it is necessary to develop and implement a national program for river restoration, which would provide a set of measures aimed at reducing anthropogenic pressure on river and floodplain ecosystems on the one side and to restore natural riverbeds and floodplains on the other side. The program should be based on the transition to a landscape type of water management, when the landscape of a river valley with all-natural and anthropogenic objects is considered as a whole.

\section{CONCLUSIONS}

The researched areas of the Ros river are characterized by a fairly complete species composition of macrophytes - 33 species (that belong to 16 families) were identified. According to the ecological structure of the flora 4 subgroups have been identified: submerged hydrophytes (26\%), hydrophytes with floating leaves (42\%), free-floating hydrophytes (16\%), and helophytes (16\%). The dominant species are Carex acuata; Carex acutiformis, subdominants - Potamogeton berchololdii; Potamogeton obtusifolius. In some places, the cenoses is formed by the species Potamogeton, Lemna minor, form thickets that are characterized by a total projective coverage from 60 to $100 \%$.

According to the modified Mayer's index, the average indicator is 16 points. The water is of the third quality class, moderately polluted, $\beta$-mesosaprobic zone. Grouping of macrophytes by three groups allowed us to establish that the highest indicator is $\mathrm{MI}=18$, the indicator of which is Lemna minor, when the index $\mathrm{Mi}=15$ it means, that indicators of the water body are species Potamogeton berchololdii, which has reached a critical threshold of water pollution and fourth quality class, it is extremely dangerous and meets zone $\alpha$-mesosaprobic.

The macrophytic index (MI) in the studied areas ranges from 5 to 8 . The average MI is 6 and it corresponds to the third class of water in the category - "polluted" and corresponds to the $\beta$-mesosaprobic zone. Thus, this water is not suitable for consumption and recreational purposes.

To maintain and improve the ecological condition of the Ros river, it is necessary to take many measures aimed at organizing public actions and eliminating the factors of negative impact on the river. In particular, to 
modernize treatment facilities at enterprises that discharge wastewater. It is also necessary to organize the coastal protection zone (CPZ) and its separation from the gardens by plantings willows or any shrubs.

\section{SUMMARY}

Due to the strong anthropogenic impact, the state of aquatic ecosystems is deteriorating. The inflow of pesticides and chemicals from agricultural lands, pollution by household waste, shallowing leads to changes in the biodiversity of the ecosystem of the Ros river. The study during 20002017 shows changes in the flora and fauna of the river, which is relevant today. The analysis of the literare shows that within the valley of the river Ros there is flora and fauna that is listed in the Red Book of Ukraine. In addition, there are habitats of rare syntaxon listed in the "Green Book of Ukraine". This is the basis for the inclusion of the river valley to the Emerald Network. Studies conducted in 2018-2020 along the shoreline of the Ros River in Bila Tserkva showed a great diversity of macrophytes. In the first, second, third, and fourth zones of the coastline, there are species of the family Cuperaceae - Carex acuata, Carex acutiformis, Carex elata, Carex pseudocyperus, Eleocharis aciculare, Scirpus lacustris and the family Potamogetonaceae - Potamogeton berchololdii, Potamogeton obtusifolius, Potamogeton pectinatus, Potamogeton trichoides, Potamogeton compressus, which are indicators of water pollution. The degree of overgrowth of the water body is defined as medium and high and ranges from $40 \%$ to $60 \%$. In some places, the species Potamogeton and Lemna minor form thickets with a total projective cover of 60 to $100 \%$, which indicates waterlogging of the water body. In addition, in the summer due to the low speed of the flow, the phenomenon of water blooms is observed. The determined indicators of the Mayer's index (16) and the Macrophytic index (6) indicate the $\beta$ - mesosaprobity of the water body. Water has $3^{\text {rd }}$ quality class. Along the shoreline of the Ros river in Bila Tserkva the water is moderately polluted.

\section{REFERENCES}

1. Аркадіївна А. Рослинність долини р. Рось: синтаксономія, антропогенна динаміка, охорона. $2005 . \quad$ URL: https://docviewer.yandex.ua.

2. Бабій П.О. Річка Рось та ії використання. Київ : Інтерпрес ЛТД, 2016. 124 c. URL: https://rovrrosi.gov.ua/images/user/files/Babij-29-02$16 \% 20(1) . p d f$.

3. Білявський Г.О. Основи екології : підручник. Київ : Либідь, 2006. 324 c. URL: http://pmd.edukit.lviv.ua/Files/downloads/.pdf. 
4. Гавриленко О.П. Екогеографія України : навчальний посібник. Київ : Знання, 2008. 128 с. URL: https://textbook.com.ua/ekologiya/1473446082.

5. Гамалій І.П. Екологічний стан водних антропогенних ландшафтів басейну р. Рось. Наукові записки Вінницького державного педагогічного університету імені Михайла Коцюбинського. Серія «Географія». 2007. Вип. 13. С. 134-139. URL: http://nbuv.gov.ua/UJRN/Nzvdpu_geogr_2009_19_7.

6. Гамалій І.П. Еколого-географічні аспекти водних ландшафтноінженерних систем басейну р. Рось. Київ, 2008. URL: https://docviewer.yandex.ua.

7. Географічна енциклопедія України : у 3-х т. / редкол.: О.М. Маринич (відп. ред.) та ін. Київ : Українська радянська енциклопедія» ім. М.П. Бажана, 1989. Т. 1: А-Ж. 416 с. URL: http://irbis-nbuv.gov.ua/ulib/item/0002146.

8. Гідробіологічний режим і стан річкової флори та фауни. URL: http://www.novaecologia.org/voecos-2369.

9. Определитель высших растений Украины / Д.Н. Доброчаева и др. Киев : Наукова думка, 1987. 548 с.

10. Звіт з оцінки впливу на довкілля виконання робіт щодо відновлення гідрологічного режиму Гідрологічного заказника «Зелені криниці», що розташований за межами села Ординці на території Левківської сільської ради Погребищенського району Вінницької області. Вінниця 2019. 59 c. URL: http://eia.menr.gov.ua/uploads/ documents/2062/reports/dbb6daa358ad77edf99ae2a37f78f05d.pdf.

11. Зеленая книга Украинской ССР / под общ. ред. Ю.Р. ШелегСосонко. Киев : Наук. думка, 1987.

12. Зеркалов Д.В. Екологічна безпека та охорона довкілля : монографія. Київ : Основа, 2011. URL: https://docviewer.yandex.ua/?url=http\%3A\%2F\%2Fzerkalov.org.

13. Карпова Г. Оцінка екологічного стану водойм методами біоіндикації. Бережани, 2010. 32 с. URL: https://www.necu.org.ua/wp.content/uploads/bioind_book_2010.pdf.

14. Куземко А.А. Охорона флори і рослинності долини р. Рось. Украӥнський ботанічний журнал. 2002. Т. 59. № 5. С. 569-577.

15. Куцонь Ю.А. Сучасний стан рибного населення басейну річки Рось. 2010. URL: http://librar.org.ua/sections_load.php?s= biological_sciences\&id=1582\&start $=1$.

16. Определитель высших растений Украины / по ред. Д.Н. Доброчаева и др. Киев : Наукова думка, 1987. 548 с.

17. Романенко В.Д. Основи гідроекології : підручник. Київ : Обереги, 2001. 728 c. URL: http://nubip.edu.ua/sites/default/files/ 
u104/\%D0\%9F\%D1\%96\%D0\%B4\%D1\%80\%D1\%83\%D1\%87\%D0\%BD \%D0\%B8\%D0\%BA_6.pdf.

18. Особливості гідрохімічного режиму р. Рось / В.К. Хільчевський та ін. Гідрологія, гідрохімія і гідроекологія. 2007. T. 12. C. 132.

19. Червона книга України. Рослинний світ / за ред. Я.П. Дідуха. Київ : Глобалконсалтинг, 2009. 900 с.

20. Шваюн І.В. До питання видового складу іхтіофауни р. Рось. Тези доповідей V державної науково-практичної конференції «Аграрна наука - виробництву», м. Біла Церква, 23-25 листопада 2006 р.. Біла Церква, 2006. Ч. 1. С. 118.

21. Шевчук I.O. Екологічні проблеми річки Рось. 2013. URL: http://xreferat.com/112/2210-1-g-droekolog-chna-oc-nka-r-chki-ros.html.

22. Мережа NATURA 2000 як інноваційна система охорони рідкісних видів та оселищ в Україні / Д.В. Ширяєва та ін. Матеріали науково-практичного семінару, м. Київ, 15 лютого 2017 р. / Серія: "Conservation Biology in Ukraine». Вип. 1. С. 234-238. URL: http://uncg.org.ua/wp-content/uploads/2019/04/UNCG1-Natura2000s.pdf.

\section{Information about the authors:} Lavrinenko V. M.,

Candidate of Biological Sciences,

Senior Teacher at the Department of Ecology of the Faculty of Natural and Geographical Education and Ecology National Pedagogical Dragomanov University 9, Pirohova str., Kyiv, 01601, Ukraine

Kompanets E. V., Candidate of Agricultural Sciences, Associate Professor at the Department of Ecology of the Faculty of Natural and Geographical Education and Ecology

National Pedagogical Dragomanov University 9, Pirohova str., Kyiv, 01601, Ukraine 